\title{
Tomasz Wojewodzic
}

Wiesław Musiał

\section{Trwanie i upadek drobnych gospodarstw rolnych - zastosowanie analogii w naukach przyrodniczych i społecznych*}

Streszczenie: Praca stanowi próbę zastosowania metody analogii do opisu zjawisk oraz objaśniania procesów o charakterze ekonomicznym i społeczno-ekonomicznym. Metodę analogii zastosowano do objaśnienia podobieństw w przebiegu wybranych procesów i ich następstw w sferze ekonomii, przyjmując za punkt odniesienia zjawiska obserwowane w przyrodzie. Nauki ekonomiczne, jako relatywnie młoda dziedzina poznania i wiedzy, od ponad stu lat wykorzystują metody analizy stosowane w znacznie starszych i lepiej oprzyrządowanych metodycznie i aparaturowo naukach przyrodniczych, głównie w fizyce i w biologii. Zastosowanie metod nauk przyrodniczych do analizy i opisu procesów gospodarczych nie tylko stanowi oryginalny i twórczy proces myślowy, pozwalający na lepsze zrozumienie procesów ekonomicznych, ale daje również szanse na wypracowanie nowej wiedzy i rozwiązań stymulujących pożądane procesy gospodarcze. Przedmiotem rozważań w prezentowanym opracowaniu są głównie drobne gospodarstwa rolne, których przyszłość jako grupy wydaje się mocno niepewna. Przeprowadzone badania wykorzystujące metodę analogii wskazują, że szansą na ich przetrwanie może być strategia bazująca na zachowaniach wszystkożernego ślimaka (dywersyfikacja dochodów), stopniowo i powoli realizującego swój cel, chowającego się w sytuacjach zagrożenia; jak również sposób zachowania gołębia, tj. podmiotu ustępującego, wycofującego się z rynków opanowanych przez producentów masowych (jastrzębie), niepodejmującego walki z silniejszymi, ale poszukującego bezpiecznych miejsc (nisz rynkowych) niestanowiących pola zainteresowania wzajemnie wyniszczających się drapieżników. Taka filozofia działania dobrze wpisuje się w koncepcje rolnictwa wielofunkcyjnego, dywersyfikację działalności gospodarstw rolnych oraz wzrost zaangażowania drobnych gospodarstw rolnych w realizację funkcji środowiskowych i rozwijanie produkcji wysokiej jakości żywności.

Słowa kluczowe: gospodarstwo rolne, analogia, ewolucja, upadek ekonomiczny.

Dr hab. inż. Tomasz Wojewodzic, Instytut Ekonomiczno-Społeczny, Uniwersytet Rolniczy w Krakowie, al. Mickiewicza 21, 31-120 Kraków, rrtwojew@cyf-kr.edu.pl; prof. dr hab. inż. Wiesław Musiał, Instytut Ekonomiczno-Społeczny, Uniwersytet Rolniczy w Krakowie, al. Mickiewicza 21, 31-120 Kraków, rrmusial@ cyf-kr.edu.pl.

* Publikacja została sfinansowana $\mathrm{z}$ dotacji na utrzymanie potencjału badawczego przyznanej przez MNiSW. 


\section{Wprowadzenie i uwagi metodyczne}

Ekonomia, a szczególnie ekonomika rolnictwa ze względu na zainteresowanie ziemią wraz z towarzyszącymi jej zasobami naturalnymi, jak również człowiekiem i jego działalnością produkcyjną, wpisuje się w istotę nauk przyrodniczych, których celem jest poznawanie złożoności przyrody. Sam człowiek występuje tu w podwójnym charakterze, będąc zarówno podmiotem, jak i przedmiotem poznania. Zainteresowanie człowiekiem w naukach ekonomicznych wynika $\mathrm{z}$ chęci rozpoznania jego potencjału i kreatywności w modelowaniu zmian. Nauki przyrodnicze, które mieszczą w sobie wielość i złożoność dziedzin poznania, tj. m.in.: biologię, medycynę, chemię oraz fizykę, są bardziej zaawansowane w zakresie rozpoznania struktur i przebiegu procesów przyrodniczych, aniżeli znacznie młodsze nauki ekonomiczne skupione na rozpoznaniu, ocenie i stymulowaniu zjawisk ekonomiczno-społecznych. Wypracowały one także olbrzymi samodzielny aparat poznawczy, w tym adekwatne metody tworzenia nowej i oryginalnej wiedzy naukowej. Wiedza ta może mieć również odniesienie, a nawet zastosowanie do pogłębiania procesów poznawania zjawisk społeczno-ekonomicznych, zwłaszcza w rolnictwie, które jako dział gospodarki ma ścisłe powiązania z przyrodą ożywioną i ekologią.

Duże nadzieje w związku z próbami zastosowania metod badawczych fizyki w badaniach ekonomicznych wiązali już ekonomiści działający na przełomie XIX i XX w. Na uwagę zasługuje m.in. praca Zygmunta Herynga Logika ekonomii (1896), w której autor dowodził, że jednym ze sposobów na znalezienie dobrego opisu procesów gospodarczych będzie spojrzenie na nie przez pryzmat wypracowanej przez fizyków „nauki o energii”. Alternatywę dla takiego mechanistycznego widzenia ekonomii stanowiła wizja analizy ekonomicznej oparta na analogiach biologicznych (Kwaśnicki 2001).

W naukach empirycznych według Stanisława Stachaka (2013) upatrywać należy największych możliwości metodycznie ścisłego poznawania świata. Natomiast w naukach ekonomicznych możliwości te są ograniczone, co wynika z trudno mierzalnej, wyjątkowo dużej nieprzewidywalności i zmienności w zakresie zachowania ludzi, którzy podlegają obserwacji. Badania ekonomiczne obejmują z reguły różne zjawiska, w których nie jest możliwe zastosowanie powtarzalnego eksperymentu, a w zasadzie (poza nielicznymi wyjątkami), w ogóle nie jest możliwe prowadzenie eksperymentu, np. na czynnym przedsiębiorstwie (gospodarstwie rolnym). Zachowania człowieka można też próbować odnieść do zachowania podmiotu gospodarczego, którym kieruje, w którym pracuje lub które tylko obserwuje, bada czy ocenia. Można się tu doszukiwać podobieństw, rozważań rozszerzających, analogii zachowań czy też podobnych reakcji przyczynowo-skutkowych, jakie występują w ekologii. 
Praca stanowi próbę zastosowania metody analogii do opisu zjawisk oraz objaśniania procesów o charakterze ekonomicznym i społeczno-ekonomicznym. Metodę analogii wykorzystano do objaśnienia podobieństw w przebiegu wybranych procesów i ich następstw w sferze ekonomii oraz w przyrodzie. Występowanie w sposób permanentny (przemienny lub alternatywny) procesów upadku, odradzania się i rozwoju zarówno w przyrodzie, jak i w gospodarce daje podstawę do wykorzystania metody analogii do rozpoznania rozwoju, regresu funkcjonowania i upadku podmiotów gospodarczych. Przedmiotem rozważań w prezentowanym opracowaniu są głównie drobne gospodarstwa rolne, mające ze swej natury organiczny charakter, łączące w sobie cechy gospodarstwa domowego i podmiotu gospodarczego. Ich duża liczba, a stąd zmienność wewnętrzna, złożoność i różnorodność sprawiają, że stanowią one grupę dobrą do badań i obserwacji różnorodności zachowań w funkcjonowaniu na rynku oraz w szerokim i często skomplikowanym, zmieniającym się otoczeniu instytucjonalnym. W prowadzonych analizach przyjęto za filozofią przyrody założenia, że zjawiska gospodarcze zachodzą według stałych praw natury. Człowiek, będąc składową przyrody, w obszarze gospodarki kieruje się rozumem, wiedzą i doświadczeniem, ale także egoizmem, który skłania go do działania we własnym interesie (Sułek 1979; Manteuffel 1987). W analizie zjawisk regresu i upadku gospodarstw rolnych poszukiwano analogii w odniesieniu do zjawiska entropii, procesów konkurencji w świecie ożywionym i towarzyszących im zachowań dostosowawczych w sferze ekonomii. Wykorzystano również opisy charakterystycznych zachowań człowieka w sferze społecznej, w tym w obszarze kultury, tj. dążenia do rozwoju i poprawy swojego bytu wobec stałego zagrożenia nieskutecznością, zawodnością czy niepowodzeniem własnych działań.

\section{Istota poznania poprzez analogie}

Kreacja wiedzy naukowej, ale i potocznej, odbywa się głównie poprzez myślenie abstrakcyjne, co pozwala badaczowi na porządkowanie, przetwarzanie zmysłowe i wypracowanie nowej wiedzy. Rozważania naukowe $\mathrm{z}$ reguły obejmują bardzo złożone procesy myślowe, których celem jest wypracowanie pewnych, w założeniu nowych ocen (sądów) i teorii. Gdy posługujemy się dedukcją, czyli wyprowadzonym z logicznego myślenia wynikaniem: od ogółu do szczegółu, to takie objaśnianie czy wnioskowanie można zaliczyć do metod rozumowań pewnych. W nauce stosuje się także wiele metod (lub podejść metodycznych), które ze względu na mniejszą siłę dowodową lub wymóg wystąpienia dodatkowych uwarunkowań można zaliczyć do metod rozumowań niepewnych. Wnioskowanie dedukcyjne, jak podaje Stachak (2013), może być uznane za niezawodne, gdy zostało oparte na prawdziwych przesłankach oraz wykonane poprawnie metodycznie, tj. zgodnie z prawami 
logiki. Takiej pewności nie można niestety zakładać przy powszechnie stosowanym, także w naukach ekonomicznych, wnioskowaniu indukcyjnym, w którym dla przybliżenia poprawności wnioskowania konieczne jest przeprowadzenie wielu dodatkowych zabiegów metodycznych (rozumowań) (Nowak 2008). Do kategorii metod rozumowań niepewnych można zaliczyć także podejście redukcyjne, które służy do wyjaśniania faktów oraz indukuje metodę enumeracyjną stosowaną do poznawania prawidłowości, powtarzalności danych zjawisk, zaszłości, stanów i procesów, poprzez znajdowanie racji, potwierdzeń czy też uzasadnień takich zachowań. Indukcja może być dzielona na indukcję zupełną i niezupełną. Indukcja zupełna obejmuje obserwacje wszystkich obiektów badawczych danej klasy (populacji), a niezupełna tylko części z tych obiektów lub procesów.

Do indukcji enumeracyjnej niezupełnej podobne jest uogólnienie, czy też wnioskowanie przez analogię. Jest to rozumowanie i ocena przeprowadzona na podstawie właściwie dobranego przykładu mającego logiczne punkty odniesienia. $Z$ reguły jest ona oparta na przesłankach jednostkowych i stąd prowadzić może także do wniosków jednostkowych. Metoda ta zakłada, że prawidłowość dotycząca pewnej liczby przypadków powtórzy sie także w kolejnych przypadkach. Wnioskowanie przez analogię, choć traktowane jako metodycznie mniej pewne, a nawet zawodne, może być jednak inspirujące do poszukiwania nowych sposobów oceny zjawisk i odkrywania albo poszerzania ocen, prawidłowości przenoszonych z jednej sfery życia czy dziedziny naukowej na drugą, np. z ekonomii na politykę, z fizyki na ekonomię, czy z ekologii na zachowania ludzi. Rozumowaniu przez analogię przypisać można duże znaczenie heurystyczne, tj. inspirujące, ale również wypracowanie nowej formy poznania i opisu zjawisk i procesów. Bardzo ważna jest tu jednak strona metodyczna dotycząca sposobów dokonania percepcji oraz doboru przykładów i wymagań formalnych w dobrze porównywanych obiektów (desygnatów). Szczególnie gdy dotyczą one różnych dziedzin poznania naukowego, w tym świata ożywionego (przyrody) i nieożywionego, np. podmiotów, w których człowiek prowadzi swoją działalność gospodarczą. Analogia opiera się na poszukiwaniu tych samych relacji w różnych warunkach lub zastosowaniu tych samych schematów rozumowania w odmiennych warunkach. Ułatwia także przenoszenie wiedzy w zakresie konkretnych zachowań, rozwiązań i spodziewanych następstw z jednego problemu czy przykładu na drugi, który występuje obecnie lub może się zdarzyć w dłuższej perspektywie czasowej. Aby analogia jako metoda rozumowania, analizy i wnioskowania była zastosowana poprawnie, musi jednak spełnić określone warunki metodyczne, tj. dostrzeżenia relacji, dostrzeżenia różnic, wieloaspektowości analiz, poszukiwania reguł, np. powtarzalnych lub incydentalnych zachowań, i ich ostrożnego wykorzystania (interpretacji). Opiera się w porównaniach także na odrzucaniu znanych zasad czy też reguł zachowań i poszukiwaniu pozornie 
niemożliwych lub wcześniej nieznanych porównań, powiązań i rozwiązań. Można to sprowadzić także do „oswajania dziwności” i szukania czegoś innego, wyrażania odmiennych ocen w sytuacjach i procesach dobrze znanych. Analogia w naukach ekonomicznych była stosowana od dawna i dotyczyła wielu sfer analizy przebiegu stanów, zjawisk, procesów i zachowań. Analizując drogi rozwoju rolnictwa światowego, Franciszek Tomczak (2006) wskazał miejsce polskiego rolnictwa w zakresie wydajności pracy, zmiany w zasobach i organizacji podmiotów rolnych. Przez analogie przemian wyznaczał hipotetyczną drogę, jaką podążać będzie polskie rolnictwo w przyszłości, biorąc za punkt wyjścia najbardziej rozwinięte kraje świata. Piotr Sztompka (2010), objaśniając wizję dziejów, zwrócił uwagę na teorie modernizacji, w tym trajektorie rozwoju, którymi podążają poszczególne kraje. Wzorce przemian i nowoczesności istnieją w cywilizacji Zachodu i ulegają szerokiej dyfuzji. Kraje uboższe i opóźnione najczęściej rozwijają się przez naśladowanie.

Związki i analogie pomiędzy prawidłowościami zachowań w przyrodzie, jak również rozwinięcia praw przyrody w sferze ekonomii podejmowane są często w pracach badawczych. Mieczysław Dobija i Bartosz Kurek (2009) poszukiwali analogii pomiędzy opisami pracy znanymi w fizyce i sposobami analizowania pracy w naukach ekonomicznych. Natomiast w pracy Kamili Musiał i Wiesława Musiała (2016) podjęto zagadnienie konkurencyjności w świecie zwierząt i gospodarce. Ryszard Manteuffel (1987), analizując w swoich rozważaniach filozoficzno-ekonomicznych przyrodę wprzągniętą do produkcji rolniczej, wskazywał na podobieństwo zachowań świata ożywionego i produkcji rolniczej, która próbuje rozwijać i multiplikować efekty gospodarstw rolnych na bazie obserwacji przyrody. Do dyscyplin przyrodniczych odwoływała się również Dominika Milczarek-Andrzejewska (2014), analizując zjawisko „siły” w nurtach nauk ekonomicznych. Jest to zgodne z opinią Łukasza Hardta (2015), który pisząc o granicach ekonomii, zwrócił uwagę na konieczność poszerzenia zakresu i metodologii prowadzonych analiz ekonomicznych. Odwołując się do rozprawy Jerzego Wilkina (2014), stwierdza on, że ekonomia powinna w większej mierze odwoływać się do nauk filozoficznych i niejako uwolnić się ze zbyt sztywnego gorsetu metodologicznego. Stawia to także pytanie, jakie są granice metod ekonomii, i stwierdza: „[...] jeśli hipotetycznie przyjąć, że nie ma żadnych restrykcji co do doboru metod i narzędzi, którymi mogą się posługiwać ekonomiści, to czy to oznacza, że ekonomię będzie można stosować do każdego typu zagadnień empirycznych, a więc że ekonomia nie będzie miała granic?" (Hardt 2015, s. 49). Jest też więc postawiona odważna teza w stosunku do metodycznych założeń prezentowanych w pracy, przeciwstawiająca „imperializm ekonomii” hegemonii praw przyrody, które dotyczą także ekonomii.

Podejście do badań oparte na analogii powinno być stosowane z wielką ostrożnością. Szczególnie ważne jest to wówczas, gdy poszukujemy analogii w przebiegu 
procesów czy zjawisk rozpatrywanych w sferze szeroko rozumianej ontologii. Wewnątrz danej branży czy też dyscypliny poznawczej łatwiej o analogię pełną lub bardzo duże podobieństwo. Gdy oddalamy się ze sfery analiz przyjętej dla danej dyscypliny naukowej, wówczas zachodzące między nimi analogie mogą być cząstkowe, a nawet śladowe (wówczas powinny być pomijane). Analogii można się doszukiwać w bardzo wielu sferach, którymi zainteresowana jest ekonomia.

\section{Schyłkowość i upadek drobnych gospodarstw rolnych - istota zjawiska}

Populacja indywidualnych gospodarstw rolnych w Polsce jest bardzo liczna, szacuje się, że według różnych kryteriów delimitacji może ona liczyć od 1250 tys. do nawet 2900 tys. jednostek. Jednocześnie występuje w tej grupie podmiotów bardzo duża zmienność wewnętrzna i różnorodność kierunków, skali produkcji, typów, a także sposobów organizacji. Poddając analizie gospodarstwa drobne, tj. o powierzchni 1-5 ha UR, których liczbę szacuje się na ok. 1362 tys., można wśród nich wyróżnić trzy podstawowe grupy podmiotów:

- gospodarstwa inwestujące, rozwojowe, stosunkowo nieliczne, produkujące intensywnie,

- gospodarstwa samozaopatrzeniowe, dla których ważnym celem jest produkcja żywności na potrzeby własne, nadmiar produkcji dostarczają one na rynek, pozyskując w ten sposób środki na prowadzenie kolejnych cykli produkcyjnych, chętnie korzystają ze wsparcia w ramach wspólnej polityki rolnej, a transfery budżetowe stanowią u nich główną część dochodów netto,

- gospodarstwa nierozwojowe, które z racji braku możliwości (i determinacji) do rozwoju produkcji zaniechały prowadzenia reprodukcji rozszerzonej majątku, unowocześniania technologii wytworzenia, redukują poziom produkcji i znalazły się na ścieżce recesywnej.

Istotą drobnych rodzinnych gospodarstw rolnych jest jedność gospodarstwa jako podmiotu produkcyjnego (i np. usługowego) i gospodarstwa domowego. Dwuzawodowość lub wielozawodowość rodzin rolniczych pozwala na przejściowe, a czasem nawet na długofalowe dofinansowanie funkcjonowania gospodarstwa $\mathrm{z}$ dochodów nierolniczych. Jest to także jeden $\mathrm{z}$ ważniejszych wyznaczników trwałości tych podmiotów, które mogą przez relatywnie długi czas funkcjonować, nie dając dochodów, a nawet przynosząc straty. W obrębie tej grupy nie występują tzw. spektakularne upadki lub bankructwa, a następnie tworzenie nowych gospodarstw rolnych na bazie likwidowanych, jak to jest powszechne w innych działach gospodarki. Specyfika tej formy władania ziemią i prowadzenia lub podtrzymania działalności produkcyjnej pomimo niskiej wydajności pracy i pojawiającego się braku uzasadnienia ekonomicznego wynika często ze względów społecznych 
i kulturowych (Wojewodzic, Musiał 2014). Uzyskiwanie przez rodzinę rolniczą dochodów pozarolniczych może być pierwszym sygnałem wygaszania działalności rolniczej. Często jednak dodatkowe dochody są wykorzystywane na dofinansowanie rozwoju gospodarstwa lub procesu produkcji, aby zapewnić rodzinie dodatkowe korzyści. Korzyści te mogą być konsumowane na bieżąco lub w sposób odroczony w czasie. Można do nich zaliczyć m.in.: dostęp do żywności wyższej jakości, wzrost wartości ziemi, zabezpieczenie minimum egzystencjonalnego na wypadek utraty pracy pozarolniczej, ale także prawa do korzystania z preferencyjnych systemów ubezpieczeń i związanych z nimi świadczeń.

Przejawów upadku produkcyjnego i ekonomicznego gospodarstw jest wiele i można je podzielić na zmniejszające i zwiększające stan zasobów oraz intensywność angażowania się w działalność rolniczą (rys. 1). Procesom recesywnym

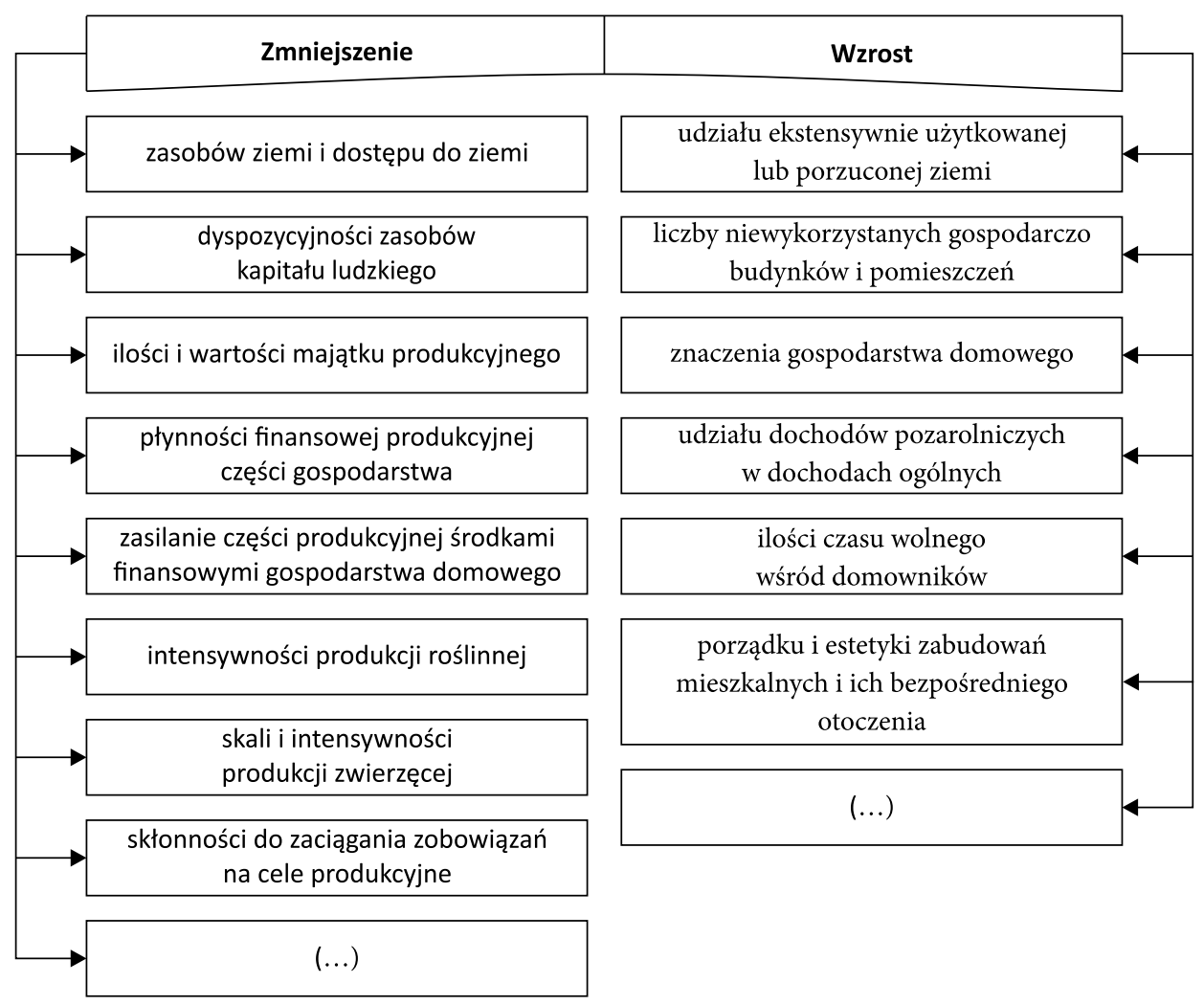

Rysunek 1. Symptomy upadku produkcyjnego i ekonomicznego gospodarstwa Figure 1. Symptoms of the farm's economic and production decline

Źródło: badanie własne.

Source: Own study. 
w gospodarstwach rolnych towarzyszą zwykle mało efektywne próby różnych działań dostosowawczych mających głównie na celu odsunięcie w czasie pełnej, formalnej i faktycznej likwidacji gospodarstw oraz zabezpieczenie uwalnianych zasobów przed degradacją fizyczną i ekonomiczną.

Ocena zaawansowania procesów upadku gospodarstw rolnych przysparza wielu trudności. Ewolucyjny, rozciągnięty w czasie charakter procesu powoduje, że w krótkiej perspektywie czasowej dla obserwatora zewnętrznego odbywa się on niemal niezauważalnie. Stąd też nawet wśród ekonomistów rolnictwa brak powszechnego odczucia, że obecnie większość drobnych gospodarstw rolnych znajduje się na ścieżce upadku produkcyjnego i ekonomicznego. Sam proces regresu lub upadku gospodarstw może mieć bardzo zróżnicowany przebieg, dotyczyć w różnej mierze poszczególnych składników majątkowych. Zasoby gospodarstwa mogą stanowić również dobrą bazę wyjściową do podjęcia pozarolniczej działalności usługowej i produkcyjnej (Wojewodzic 2012).

\section{Upadek gospodarstwa drobnego - poszukiwanie analogii}

Konkurencja pomiędzy organizmami żywymi występuje wówczas, gdy wiele osobników korzysta z tych samych, ograniczonych zasobów. Prawidłowością jest, że konkurujące organizmy wzajemnie wpływają na obniżenie swojego dostosowania. Wynikiem konkurencji może być albo wyeliminowanie partnerów, albo ustalenie równowagi w korzystaniu z zasobów i koegzystencja. W świecie zwierzęcym wyróżniamy konkurencje płciową i konkurencję o zasoby. Konkurencja, a często związana z nią również agresja dotyczą przede wszystkim konkurowania o zasoby naturalne, głównie o pożywienie i schronienie. Może się ona rozwinąć lub zaostrzyć, gdy zagęszczeniu populacji towarzyszy brak niezbędnych zasobów (Wilson 2000). Zachowanie to można również odnieść do sfery ekonomii, w tym ekonomii rolnej.

Analogie można także zaobserwować w zakresie zmian wywoływanych walką konkurencyjną w świecie zwierzęcym a walką pomiędzy podmiotami gospodarczymi w życiu ekonomicznym. Podejście ewolucyjne w naukach społecznych zostało spopularyzowane przez Herberta Spencera (Kwaśnicki 2009). Spencer (1892, s. 10) rozwojem ewolucyjnym nazywał „zmiany od nieokreślonej, niespójnej jedności do określonej, spójnej, niejednorodności poprzez stałe zróżnicowanie”. Jest on twórcą określenia „przeżyje najbardziej przystosowany”, wskazał także na celowość i uzasadnienie poszukiwania analogii w naukach biologicznych i w ekonomii. W przyrodzie nieustannie trwa „wyścig zbrojeń, tj. proces zmian dostosowawczych, np. pomiędzy pasożytami i ich ofiarami (żywicielami). Całkowite dostosowanie się do środowiska osobników konkurujących o byt nie jest możliwe. Jeżeli nawet gatunki konkurujące osiągną lepsze dostosowanie do środowiska 
w wyniku ulepszeń genetycznych i ewolucji, szansa na ich przetrwanie nie poprawi się. Dzieje się tak dlatego, że ich konkurenci także doskonalą się, tj. „zbroją się” i nieustannie ulepszają swoje dostosowanie. Organizmy, a właściwie ich programy genetyczne, muszą więc stale dostosowywać się do zmieniających się warunków środowiskowych. Unikanie konkurencji, a przez to brak potrzeby doskonalenia się i dostosowań do ciągle zmieniających się warunków środowiska grozi zagładą danego gatunku (Musiał, Musiał 2011). Można tu doszukać się wielu analogii do funkcjonowania w warunkach rynkowych gospodarstw rolnych - zwłaszcza tych mniejszych, wysoce zróżnicowanych, występujących w dużej liczbie. Są tam także „agresorzy i ofiary”, tj. podmioty bardzo sprawnie wykorzystujące nadarzające się okazje na osiągnięcie korzyści, i takie, które padają ich ofiarą. Gospodarstwa przez cały okres swojego życia ekonomicznego muszą się wewnętrznie zmieniać, regenerować siły, „zbroić się”, aby przeżyć, przetrwać. Jednak funkcjonują one w określonym środowisku ekonomicznym i instytucjonalnym, które także podlega zmianom. Pełne dostosowanie nawet pojedynczego gospodarstwa nie jest więc możliwe, stąd też istnieje nieustanne zagrożenie dla jego bytu i życia ekonomicznego. Gospodarstwo w kontakcie z otoczeniem może stosować także „barwy ochronne”, które pozwalają na kamuflaż, aby „być ukrytym” dla tych, z którymi nie chce się kontaktować w sytuacji, gdy jest to ważne dla jego interesu. Gdyby gospodarstwo nie działało w warunkach konkurencyjnych, to nie uczestniczyłoby, analogicznie jak to się dzieje w przyrodzie, w „wyścigu zbrojeń”. Wówczas nie doskonaliłoby struktury czynników produkcji, zrządzania czy też marketingu. Jego ewolucja czy też przekształcenie uległoby zatrzymaniu, a w stosunku do otoczenia, w którym funkcjonuje, uległoby regresowi. Tak więc unikanie konkurencji pociąga za sobą spadek dostosowania oraz zmniejszenie otwarcia na nowe zasoby i nową organizację. Także w ekonomii, gdy analizujemy przedsiębiorstwa (gospodarstwa rolne) funkcjonujące w warunkach konkurencji, również należy spodziewać się, że „przeżyją najbardziej przystosowane". Małe podmioty produkujące zwykle wyłącznie na samozaopatrzenie, wycofujące się z wyścigu zbrojeń, są skazane na porażkę przy pierwszej próbie podjęcia gry rynkowej.

Sposób zachowania drobnego gospodarstwa rolnego składającego się z dwóch zasadniczych części: gospodarstwa rolnego (produkcyjnego), będącego de facto podmiotem ekonomicznym przynoszącym przychody, oraz z gospodarstwa domowego, stanowiącego podmiot życia rodzinnego i osłony socjalnej, można poprzez analogię odnieść do ślimaka. Ślimaki to mięczaki dostosowane do bardzo różnych środowisk życia na Ziemi. Odżywiają się one zarówno pokarmem zwierzęcym, jak i roślinnym, roślinami naczyniowymi, a także porostami i grzybami. Wiele gatunków, szczególnie żyjących w morzach, jest drapieżnikami lub prowadzi życie pasożytnicze. Muszla ślimaka stanowi jego szkielet zewnętrzny pełniący głównie 
funkcje ochronne, a w mniejszym zakresie podporowe. Ślimaki znane są z powolnego poruszania się, większość z nich jest wszystkożerna. Mięczaki te w sytuacji zagrożenia chowają głowę i nogę do skorupy, którą noszą na sobie. Ten naturalny pancerz powiększa się wraz z wiekiem i rozwojem ciała danego osobnika. Skorupę ślimaka, przyjmując odniesienie przez analogię, można porównać do gospodarstwa domowego, w którym żyje rolnik i jego rodzina. Nogę ślimaka można natomiast uznać za część produkcyjną gospodarstwa rolnego (Wojewodzic 2017), która ulega zwykle powiększeniu biologicznemu i ekonomicznemu, konkurując z innymi podmiotami o dochody potrzebne do swojego wzrostu. Część produkcyjna gospodarstwa (opisana jako noga ślimaka) w korzystnych warunkach śmiało poszukuje dogodnych warunków do zaspokojenia potrzeb całego organizmu, co sprzyja rozwojowi. W sytuacji niepowodzenia ekonomicznego lub dekoniunktury gospodarstwo rolne kurczy produkcję, poszukując innych sposobów na zaspokajanie swoich potrzeb. Często, aby przeczekać niekorzystny okres, domownicy poszukują pracy pozarolniczej lub chowają się w swojej skorupie - gospodarstwie domowym (np. ukryte bezrobocie). Nierzadko, szczególnie gdy spodziewany okres zagrożenia wydłuża się, skorupa zostaje zasklepiona. W warunkach, gdy sytuacja ekonomiczna poprawia się i wzrasta opłacalność produkcji, następuje wzrost aktywności części produkcyjnej gospodarstwa rolnego, którą w prezentowanym opisie reprezentuje głowonoga ślimaka. Ślimak wychodzi z muszli i skupia się na żerowaniu (gospodarstwo na produkcji i dostarczaniu dochodów), bacznie obserwuje niebezpieczeństwa, intensywnie powiększa swoje rozmiary.

Ścisłe powiązane ekonomicznie części produkcyjnej i bytowej w gospodarstwie rolnym oraz konkurencja o pracę i jej efekty stanowią czynniki hamujące dla rozwoju produkcji. Gospodarstwo domowe (symbolizowane przez muszlę ślimaka) i ciągła potrzeba zaspakajania jego potrzeb ogranicza możliwości i spowalnia tempo ekspansji. Jednocześnie gospodarstwo domowe daje poczucie bezpieczeństwa, stanowi miejsce, gdzie można się schować i przetrwać złe czasy, nierzadko przez długi okres. Wolne poruszanie się ślimaka można odnieść do powolnej ewolucji drobnych gospodarstw rolnych. Ostrożność w kontaktach z otoczeniem, brak skłonności do ryzyka cechują zarówno ślimaka, jak i z reguły rolników prowadzących niewielkie gospodarstwa.

Znaczenie konkurencji jako drogi prowadzącej małe, słabe podmioty gospodarcze do upadku sensu stricte lub też pozwalającej na koegzystowanie obok siebie podmiotów małych (słabych) i dużych (silnych) tłumaczy w świecie zwierzęcym koncepcja strategii ewolucyjnie stabilnej (Krzanowska et al. 1997). W wyjaśnieniu tego zjawiska zastosowanie znajduje teoria gier, w której jeden podmiot (w biologii zwierzę) jest agresorem (jastrzębiem), a drugi podmiot (zwierzę) jest osobnikiem ustępującym (gołębiem). Teoria ta pozwala również na poszukiwanie analogii, 
a tym samym odpowiedzi na pytanie, dlaczego $w$ warunkach wzajemnej konkurencji funkcjonują obok siebie gospodarstwa duże (silne) i małe (słabe). Podejmując walkę, oba zwierzęta (lub podmioty gospodarcze) z założenia mają szanse na zwycięstwo. Z teorii tej wynika, że osobnik słabszy, ustępując przy spotkaniu $\mathrm{z}$ agresorem, co prawda nie wygrywa, ale także dużo nie traci, gdyż nie wdając się w walkę, nie ponosi jej kosztów. Pojedynczy agresor, gdy będzie to w jego interesie, może wyeliminować osobniki ustępujące. W sytuacji gdy większość osobników (podmiotów gospodarczych o różnej sile ekonomicznej) jest ustępujących, np. w konkurencji o ziemię, wyższą wygraną uzyskuje agresor (podmiot agresywny, większy, silniejszy, bardziej ekspansywny), który jest w stanie zapłacić za nią wyższą cenę. Przy spotkaniu dwóch osobników ustępujących (np. rolników chcących kupić ziemię) konflikt rozwiązuje się przez przypadek, ale strat nie ma, gdyż nie dochodzi do walki konkurencyjnej. Natomiast gdy w populacji występuje duża konkurencja pomiędzy licznymi podmiotami agresywnymi, które nawzajem się wyniszczają, pojawia się często przestrzeń dla funkcjonowania podmiotów nieponoszących kosztów walki. Nie ma więc tu jedynej najlepszej strategii dla danego podmiotu, wynik bowiem zależy od strategii przyjętych przez pozostałych graczy - członków danej populacji. Żyjąc czy prowadząc działalność wśród agresorów, lepiej być ustępującym, natomiast gdy dany osobnik (podmiot) działa w otoczeniu ustępujących, dużo zyskuje, będąc agresorem (Krzanowska et al. 1997). Przekłada się to dość prosto na rynek ziemi, na którym próbują operować właściciele drobnych gospodarstw zmuszani do przyjęcia strategii „ustępowania” wobec stosujących strategie agresywne właścicieli większych podmiotów, a często również dużych graczy niebędących rolnikami. Podjęcie strategii agresywnej przez właściciela drobnego gospodarstwa rolnego mogłoby zakończyć się w dłuższej perspektywie porażką, ze względu np. na trudności w spłacie nadmiernie dużych zobowiązań zaciągniętych na zakup drogiej ziemi. Z drugiej strony wycofanie się $\mathrm{z}$ konkurencji o duże, atrakcyjne z rolniczego punktu widzenia działki i koncentracja na mniejszych działkach, znajdujących się poza zainteresowaniem dużych graczy, daje szanse na trwanie i powolny rozwój. $W$ „starciach o ziemię" pomiędzy właścicielami drobnych gospodarstw wygrana może być sprawą przypadku, sprzyjających okoliczności (np. faktu pokrewieństwa z dotychczasowym właścicielem) lub też ujawnienia się „agresywności” i determinacji do ekspansji. Analogie te można także odnieść do walki o rynki zbytu, gdzie w atrakcyjnych ekonomicznie segmentach trwa walka pomiędzy dużymi, a mali producenci, podejmując walkę, skazani byliby na porażkę. Wycofując się z atrakcyjnych, masowych segmentów rynku i poszukując nisz rynkowych, unikają agresji ze strony dużych graczy, zyskując jednocześnie przestrzeń do życia. 
O regresie lub upadku podmiotów gospodarczych decydują często zdarzenia przypadkowe, niezależne od intencji oraz poczynań jednostki, której dotyczą. Sfera działań gospodarczych może być opisana poprzez bardzo wiele zmiennych, jednak nie daje to pewności, a nawet dużego prawdopodobieństwa przywidywania przyszłości. Trudno bowiem przygotować się na sytuacje nieprzewidywalne. Nawet przywoływane w Biblii proroctwa nie stanowiły deterministycznego przedstawienia przyszłości, a były raczej ostrzeżeniem i projekcją rozwoju wydarzeń (Sedlacek 2012). Transponując te rozważania na grunt ekonomii rozwoju i upadku firm, w tym gospodarstw rolnych, należy zwrócić uwagę na znaczenie nieprzewidywalności ich przyszłego bytu. Śpiący zając może zostać zjedzony przez lisa, zanim zdąży się obudzić, może pozostać również niezauważony. Natomiast zwierzę czujne, dobry biegacz, uciskając przed napastnikiem, może wpaść w niewidoczną wcześniej pułapkę, może także szczęśliwie przeskoczyć na drugą stronę przeszkody, gdzie nie ma już agresora, a rośnie za to soczysta trawa, o której wcześniej nie wiedział. Los wielu podmiotów gospodarczych czy też drobnych gospodarstw rolnych wydaje się dziś przesądzony, mogą one jednak niespodziewanie uzyskać nowy impuls rozwoju (środki finansowe, pomysł na biznes, korzystne zmiany w otoczeniu ekonomicznym). Jednocześnie gospodarstwa rolnicze o większym potencjale ekonomicznym mogą napotkać różne trudne do przewidzenia trudności, związane np. z pułapką kredytową, brakiem następcy, problemami zdrowotnymi właściciela, jego sytuacją rodzinną, prawną, wystąpieniem klęsk elementarnych lub też w krótkim czasie serii niekorzystnych zdarzeń losowych. Sytuacje takie mogą przesądzić o przyszłości gospodarstwa, choć wcześniejsze plany i zamierzenia rolnika w tym względzie były zupełnie inne. Nawet najlepsze gospodarstwa w czasie życia jednego pokolenia mogą ulec unicestwieniu, a słabe i upadające rozwijać się, osiągając sukces. Stąd też trudno o proste wskazanie przyszłości drobnych gospodarstw rolnych, mając na względzie wszystko to, co w ekonomii da się określić jako przewidywalne (Wojewodzic 2017).

Gospodarstwo rolne, ale również cała populacja gospodarstw rolnych łącznie mogą być rozpatrywane, podobnie jak w fizyce, jako odosobnione dynamiczne układy. Ich nieuporządkowanie można rozpatrywać analogicznie jak w przypadku układów termodynamicznych. Procesy przemian ekonomicznych zachodzące w gospodarstwie rolnym lub populacji gospodarstw rolnych, tak jak w każdym układzie termodynamicznym, mają charakter jednokierunkowy i dążą do wzrostu nieuporządkowania istniejącego stanu, czyli do chaosu, entropii. Przechodzenie układu termodynamicznego $\mathrm{z}$ jednego stanu równowagi do drugiego $\mathrm{w}$ sposób spontaniczny, tzn. bez udziału czynników zewnętrznych, zawsze powoduje wzrost nieuporządkowania. Entropia układu wzrasta. W analogiczny sposób można dokonać opisu przemian zachodzących w gospodarstwach rolnych, które funkcjonując 
w warunkach konkurencji, poszukują nowego stanu równowagi. Poszukiwania te zarówno wewnątrz gospodarstwa (ujęcie mikroekonomiczne), jak i w obrębie całej zbiorowości (ujęcie makroekonomiczne) prowadzą do wzrostu nieuporządkowania, co w przypadku wielu gospodarstw może oznaczać całkowity brak dostosowania do warunków zewnętrznych, brak konkurencyjności, a w konsekwencji stagnację lub upadek. Aby nie dopuścić do wzrostu nieuporządkowania, niezbędne jest dostarczenie do tego układu energii z zewnątrz, tj. stworzenie takich rozwiązań ekonomicznych w zakresie organizacji rynku oraz w zakresie polityki rolnej, które będą spowalniały lub zatrzymają wzrost nieuporządkowania. Dostarczenie energii z zewnątrz, czyli zasilenie tego układu przez np. środki finansowe (renty ekonomiczne, subsydia), zmniejsza natężenie procesów spontanicznych prowadzących do chaosu. Stąd też dzięki realizacji m.in. polityki gospodarczej, w tym polityki rolnej, następuje regulacja dopływu środków finansowych do gospodarstw. Wdrażając narzędzia interwencjonizmu państwowego, oddziałujemy na tempo entropii gospodarstw rolnych. Biorąc pod uwagę, że procesy zachodzące w przyrodzie w sposób samorzutny zawsze mają taki sam kierunek, tj. od stanów mniej nieuporządkowanych do bardziej nieuporządkowanych, również gospodarstwo rolne dla trwania, a tym bardziej rozwoju potrzebuje energii. Energię tę stanowią zarówno praca człowieka, jak i środki finansowe. Jeżeli wielkość dostarczanej do układu pracy i kapitału jest niewystarczająca, następuje samoistny proces wzrostu nieuporządkowania i chaosu, a w konsekwencji może to prowadzić do upadku gospodarstwa.

Opis procesów upadku małych podmiotów rodzinnych, jak również schyłkowość i niską efektywność organizacji produkcji rolniczej prowadzonej w formie drobnych gospodarstw rolnych można odnieść również do sfery kulturowej. Starania rolników o przetrwanie, rozwój lub osiągnięcie innych ambitnych celów poprzez pracę w gospodarstwie rolnym można porównać do pracy mitologicznego Syzyfa. Syzyf to postać, ale i postawa człowieka, który pomimo dużej determinacji w swoich staraniach nie jest w stanie osiągnąć zamierzonego celu, tj. wtoczyć dużego kamienia na szczyt góry. Kolejne próby zawsze kończą się niepowodzeniem w momencie, gdy cel wydaje się już bliski (rys. 2). Szczyt góry stanowi alegorię odpoczynku i spokoju osiągniętego dzięki ciężkiej pracy. Starania większości rolników o zapewnienie poziomu produkcji i organizacji pracy, które umożliwią im spokojne patrzenie w przyszłość, przypominają pracę Syzyfa. Oczekiwany z utęsknieniem szczyt (cel), choć chwilowo wydaje się bliższy m.in. dzięki wzrostowi wydajności i zwiększeniu skali produkcji, to co jakiś czas ponownie się oddala. Następuje zmiana warunków gospodarowania, pogorszenie relacji cen, zmiana oczekiwań odbiorców, wzrost wymagań domowników odnośnie do poziomu życia lub nieprzewidziane zdarzenie losowe i ponownie szczyt wydaje się odległy, tak jak jeszcze kilka lat wcześniej. 


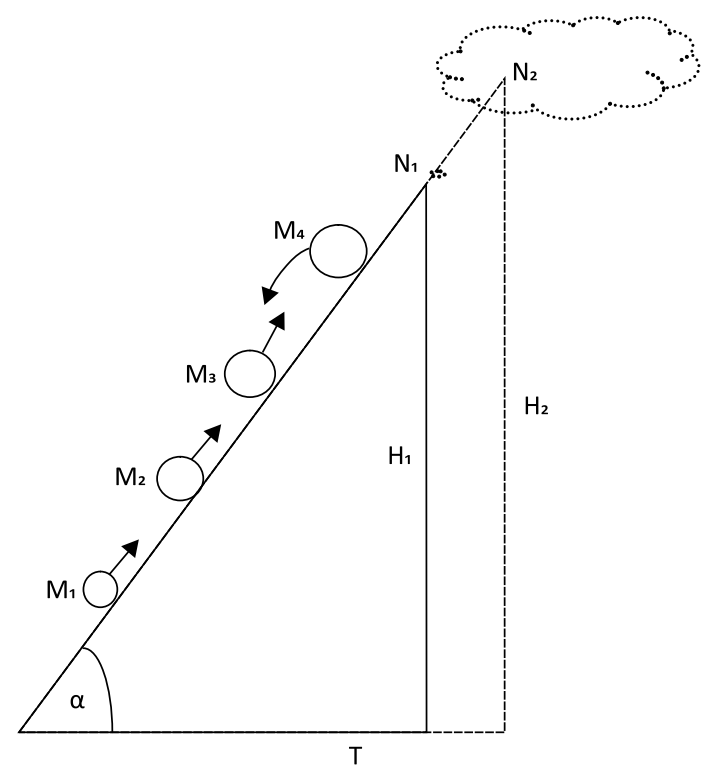

Rysunek 2. Syndrom Syzyfa - poszukiwanie analogii do nieskuteczności rozwoju gospodarstwa drobnego

Figure 2. Sisyphus syndrome - drawing analogies to semi-commercial farm's ineffective growth

Źródło: badanie własne

Source: Own study.

Przez cały okres swojego życia (T) rolnicy podejmują coraz większy trud dostosowania gospodarstwa do zmieniających się wymogów rynku. Jednocześnie na skutek wzrostu poziomu życia społeczeństwa wzrastają również oczekiwania rodziny, a tym samym „masa” (M), którą ma pchać pod górę, wraz z upływem czasu staje się coraz większa. W ten sposób pomimo włożonego trudu nigdy nie będzie w stanie doprowadzić do takiego poziomu rozwoju gospodarstwa i organizacji produkcji, aby był to szczyt, na którym mógłby odpocząć $\left(\mathrm{N}_{1}\right)$. Odzwierciedlenie skali trudności, jakie musi pokonać rolnik, stanowi wartość funkcji tg a, która może np. wynikać z polityki rolnej realizowanej wobec danej grupy gospodarstw. Rozstrzygnięcia wymaga dodatkowo kwestia: czy istnieje poziom produkcji i organizacji gospodarstwa, którego osiągnięcie można uznać za bezpieczny szczyt? Osiągnięcie poziomu $\left(\mathrm{N}_{1}\right)$ ujawni bowiem nową perspektywę $\left(\mathrm{N}_{2}\right)$ i konieczność podjęcia dalszego trudu. Jedynie w ocenie krótkookresowej zamierzony cel można uznać za ostateczny, gdyż w dłuższym horyzoncie czasowym pojawiają się kolejne cele i nowe trudności do pokonania. 


\section{Podsumowanie}

Struktura agrarna jest systemem dynamicznym, w którym na wzór układów biologicznych trwa walka o prawo do życia i rozwoju. Szczególne miejsce w tym systemie odgrywają drobne gospodarstwa rolne, podmioty z natury słabsze ekonomicznie i wydawać mogłoby się, skazane na szybkie unicestwienie. Obserwacja zjawisk znanych w przyrodzie i tworzone na tej podstawie teorie naukowe pokazują jednak, że organizmy żywe i podmioty mniejsze, słabsze mają szanse na przetrwanie, o ile w warunkach permanentnej konkurencji pozytywnie zostanie zweryfikowany ich proces dostosowawczy do zmieniających się warunków otoczenia.

Nauki ekonomiczne, jako relatywnie młoda dziedzina wiedzy, od ponad stu lat wykorzystują metody analizy stosowane w znacznie starszych i lepiej oprzyrządowanych naukach przyrodniczych, głównie w fizyce i w biologii. Zastosowanie metod nauk przyrodniczych do analizy i opisu procesów gospodarczych stanowi nie tylko ciekawy i twórczy proces myślowy, pozwalający na lepsze zrozumienie procesów ekonomicznych, ale także dający szanse na wypracowanie rozwiązań stymulujących pożądane procesy gospodarcze. Również w przypadku drobnych gospodarstw rolnych, których przyszłość jako grupy wydaje się mocno niepewna, a utrzymanie potencjału każdego z osobna wymaga ciężkiej i nierzadko syzyfowej pracy, istnieją możliwości przetrwania. Przetrwają jednak tylko te podmioty, które najlepiej dostosują swoje strategie działania do zmieniających się warunków zewnętrznych oraz będą potrafiły wykorzystać pojawiające się możliwości wsparcia instytucyjnego i finansowego dla powstrzymania swojego rozpadu (entropii). Mądra strategia drobnych gospodarstw rolnych powinna bazować zarówno na zachowaniach wszystkożernego ślimaka, stopniowo i powoli realizującego swój cel, chowającego się w sytuacjach zagrożenia, jak i gołębia, tj. podmiotu wycofującego się, niepodejmującego walki z agresywnymi jastrzębiami (dużymi podmiotami), ale poszukującego bezpiecznych miejsc (nisz rynkowych) niestanowiących pola zainteresowania wzajemnie wyniszczających się drapieżników. Taka filozofia działania dobrze wpisuje się w koncepcje rolnictwa wielofunkcyjnego, dywersyfikację działalności gospodarstw rolnych oraz wzrost zaangażowania drobnych gospodarstw rolnych w realizację funkcji środowiskowych i rozwijanie produkcji wysokiej jakości żywności ekologicznej. Drobne gospodarstwa rolne, jeżeli chcą przetrwać, muszą stale poszukiwać nisz rynkowych, analogicznie jak czyni to wiele wolno żyjących gatunków zwierząt, które ciągle dostosują się do środowiska, w którym żyją. 


\section{Bibliografia}

Dobija M., Kurek B. (2009). Istota pracy w fizyce i rachunkowości. Zeszyty Naukowe Uniwersytetu Ekonomicznego w Krakowie, 796, 33-45.

Hardt Ł. (2015). O granicach ekonomii. W: Ł. Hardt, D. Milczarek-Andrzejewska (red.). Ekonomia jest piękna? Ksiega dedykowana Profesorowi Jerzemu Wilkinowi (s. 45-57). Warszawa: Wydawnictwo Naukowe Scholar.

Heryng Z. (1896). Logika ekonomii. Zasadnicze pojęcia ekonomiczne ze stanowiska nauki o energii. Warszawa: Wydawnictwo „Głosu”.

Krzanowska H., Łomnicki A., Rafiński J., Szarski H., Szymura J.M. (1997). Zarys mechanizmów ewolucji. Warszawa: Wydawnictwo Naukowe PWN.

Kwaśnicki W. (2001). Zygmunta Herynga logika ekonomii. Gospodarka Narodowa, 10, http:// kwasnicki.prawo.uni.wroc.pl/todownload/Logika_ekonomii.pdf [dostęp: 15.01.2014].

Kwaśnicki W. (2009). Ekonomia ewolucyjna: Alternatywne spojrzenie na proces rozwoju gospodarczego. http://kwasnicki.prawo.uni.wroc.pl/todownload/ekonomia\%20ewolucyjna.pdf [dostęp: 15.01.2014].

Manteuffel R. (1987). Filozofia rolnictwa. Warszawa: PWN.

Milczarek-Andrzejewska D. (2014). Zagadnienie sił w ekonomii: Na przykładzie sektora rolno-spożywczego. Warszawa: Instytut Rozwoju Wsi i Rolnictwa PAN.

Musiał K., Musiał W. (2011). Ekstrapolacja hipotezy czerwonej królowej z nauk przyrodniczych do ekonomicznych w aspekcie konkurencyjności i postępu. Roczniki Naukowe Stowarzyszenia Ekonomistów Rolnictwa i Agrobiznesu, 13 (8), 159-164.

Musiał K., Musiał W. (2016). Konkurencja w naturze a natura konkurencyjności w gospodarce. Wybrane przykłady analogii w świecie zwierząt i ekonomii. Roczniki Naukowe Ekonomii Rolnictwa I Rozwoju Obszarów Wiejskich, 103 (3), 22-31.

Nowak S. (2008). Metodologia badań społecznych. Warszawa: PWN.

Sedlacek T. (2012). Ekonomia dobra i zła (tłum. D. Bakalarz). Warszawa: Wydawnictwo Studia Emka.

Spencer H. (1892). Essays scientific, political and speculative. New York: Appleton.

Stachak S. (2013). Podstawy metodologii nauk ekonomicznych. Warszawa: Wydawnictwo Difin.

Sułek A. (1979). Eksperyment w badaniach społecznych. Warszawa: PWN.

Sztompka P. (2010). Socjologia. Analiza społeczna. Kraków: Znak.

Tomczak F. (2006). Gospodarka rodzinna w rolnictwie. Uwarunkowania i mechanizmy rozwoju. Warszawa: Instytut Rozwoju Wsi i Rolnictwa PAN.

Wilkin J. (2014). Czy ekonomistom potrzebna jest filozofia? Warszawa: Instytut Rozwoju Wsi i Rolnictwa PAN, maszynopis.

Wilson E.O. (2000). Socjobiologia (tłum. M. Siemiński). Poznań: Wydawnictwo Zysk i Spółka.

Wohlleben P. (2016). Sekretne życie drzew (tłum. E. Kochanowska). Kraków: Wydawnictwo Otwarte.

Wojewodzic T. (2012). Divestments in the process of developing off-farm economic activity by farmers. Acta Scientiarum Polonorum. Oeconomia, 3, 77-85. 
Wojewodzic T. (2017). Procesy dywestycji i dezagraryzacji na obszarach o rozdrobnionej strukturze agrarnej. Zeszyty Naukowe Uniwersytetu Rolniczego im. H. Kołłątaja w Krakowie, 535 , seria rozprawy, 412.

Wojewodzic T., Musiał W. (2014). Wykorzystanie dywestycji w procesie likwidacji gospodarstwa rolniczego. W: P. Dec (red.). Niepewność funkcjonowania przedsiębiorstw: Bankructwa, restrukturyzacja, likwidacja (s. 215-226). Warszawa: Szkoła Główna Handlowa.

\title{
The Decadence and Decline of Small Farms - Application Analogies to Natural and Social Sciences
}

\begin{abstract}
The authors apply the analogy method to analyse economic and socio-economic phenomena. The analogy method has been used to explain similarities between selected natural and economic processes and their consequences. For over a century economic sciences - as a relatively young branch of science - have been relying on methods of analysis applied in older and better equipped natural sciences, mostly in physics and biology. The application of natural sciences' methods for the analysis and description of economic processes is not just an interesting and creative intellectual process which allows to better understand them but also gives an opportunity to develop solutions which stimulate desired economic processes. The paper focuses on semi-commercial family farms which face quite an uncertain future as a group. Based on the conducted analysis, the adoption of a specific strategy can be their chance to survive. That strategy involves both a behaviour modeled after an omnivorous snail (diversified incomes) which gradually and slowly works towards achieving its goal and hides in case of danger, and that resembling the behavior of a dove, i.e. the retreat and withdrawal from markets controlled by mass producers (hawks), avoiding confrontation with the stronger ones and seeking safe havens (market niches) in which beasts of prey fighting one another are not interested. Such a philosophy is consistent with the concept of multifunctional agriculture, the diversification of farm activities and the increased engagement of small farms in the performance of environmental functions and development of high-quality organic foods.
\end{abstract}

Keywords: farms, analogy, evolution, economic decline. 